THE DUPLICITY OF PHILOSOPHY'S SHADOW 



\section{The Duplicity of Philosophy's Shadow}

HEIDEGGER, NAZISM, AND THE JEWISH OTHER

\section{Elliot R. Wolfson}

Columbia University Press

New York 


\author{
Columbia University Press \\ Publishers Since 1893 \\ New York Chichester, West Sussex \\ cup.columbia.edu \\ Copyright (๑) 2018 Columbia University Press \\ All rights reserved \\ Library of Congress Cataloging-in-Publication Data
}

Names: Wolfson, Elliot R., author.

Title: The duplicity of philosophy's shadow: Heidegger, Nazism, and the Jewish other /

Elliot R. Wolfson.

Description: New York: Columbia University Press, 2018. | Includes bibliographical references and index.

Identifiers: LCCN 2017049988 | ISBN 9780231185622 (cloth: alk. paper) | ISBN 9780231185639

(pbk.: alk. paper) | ISBN 9780231546249 (e-book)

Subjects: LCSH: Heidegger, Martin, 1889-1976. | National socialism.

Classification: LCC B3279.H49 W627 2018 | DDC 193-dc23

LC record available at https://lccn.loc.gov/2017049988

Columbia University Press books are printed on permanent and durable acid-free paper.

Printed in the United States of America

Cover design: Noah Arlow 
To Aaron

For abiding when many others absconded 

As every past generation has had to disenthrall itself from an inheritance of truisms and stereotypes, so in our time we must move on from the reassuring repetition of stale phrases to a new, difficult, but essential confrontation with reality. For the great enemy of the truth is very often not the lie-deliberate, contrived and dishonest-but the myth-persistent, persuasive and unrealistic. Too often we hold fast to the clichés of our forebears. We subject all facts to a prefabricated set of interpretations. We enjoy the comfort of opinion without the discomfort of thought.

-JOHN F. KENNEDY, "COMMENCEMENT ADDRESS AT YALE UNIVERSITY,"

JUNE 11, 1962

The matter of thinking is always confounding-all the more in proportion as we keep clear of prejudice. To keep clear of prejudice, we must be ready and willing to listen. 
